\title{
Case of alopecia universalis associated with alemtuzumab treatment in MS
}

Verena Isabell Leussink, MD, Julia Reifenberger, MD, and Hans-Peter Hartung, MD

Neurol Neuroimmunol Neuroinflamm 2018;5:e454. doi:10.1212/NXI.0000000000000454

\author{
Correspondence \\ Dr. Leussink \\ verenaisabell.leussink@ \\ uni-duesseldorf.de
}

Alemtuzumab (Lemtrada ${ }^{\circledR}$ ) is a monoclonal antibody recognizing CD52 that selectively depletes T- and B-lymphocytes ${ }^{1}$ and is indicated for the treatment of relapsing-remitting MS (RRMS). Although it is highly efficacious, its use is associated with secondary autoimmune phenomena, such as thyroid dysfunction, immune thrombocytopenia, and glomerulonephritis. ${ }^{2}$

Alopecia areata is a form of autoimmune hair loss that can progress to the point of global hair loss, after which it is known as alopecia universalis. ${ }^{3}$

Here, we report a case of alopecia universalis in a young woman being exposed to alemtuzumab as treatment of highly active RRMS.

\section{Case report}

We report a 29-year-old woman with active RRMS, diagnosed in November 2014, who was otherwise healthy with no history of other autoimmune disorders and normal thyroid function. She had aggressive disease suffering 2 severe clinical relapses presenting with internuclear ophthalmoplegia and sensorimotor hemiparesis accompanied by a high and active lesion load on MRI. This prompted initiation of alemtuzumab treatment. Sixty milligrams of this antibody were applied over 5 consecutive days IV. Alemtuzumab was tolerated well. Since December 2014, her MS has remained clinically silent with no further relapses or disability progression. As expected, monthly laboratory controls revealed severe lymphopenia with total lymphocyte counts around $100 / \mu \mathrm{L}$ during the first months after commencing treatment. Six months after the last infusion, the patient noticed regional hair loss cumulating in generalized complete hair loss, including scalp, eyebrows, and pubic hair, within the following 3 months (figure). Otherwise, the patient was healthy. After 12 months, total lymphocyte counts were within the lower normal range $(1,200 / \mu \mathrm{L})$, with slightly decreased CD3 and CD4 counts and an increased CD19 count. A detailed laboratory workup showed normal values for all measures of thyroid functioning and absence of antithyroid antibodies. A large screening for autoantibodies revealed only low-titer antinuclear antibodies (indirect immunofluorescence test). A broad serum hormonal profiling was normal as well. A skin biopsy was performed 12 months after treatment initiation, which did not reveal any signs of local inflammation. Without any specific intervention, hair regrowth was first observed 15 months after the last infusion of alemtuzumab. At that time, all lymphocyte counts, including CD3, CD4, and CD19 subtypes, were within the normal range. Complete hair regrowth in all affected regions was seen 2 years after the last infusion. 




\section{Discussion}

Alopecia is stated as a common adverse event in patients treated with alemtuzumab in the respective Summary of Product Characteristics published by the European Medical Agency; however, a case of generalized alopecia has not been reported in the literature so far.

The exact cause of alopecia areata is still unknown. Increasing evidence supports an autoimmune origin in the context of a genetic predisposition, modified by unknown environmental factors. ${ }^{4}$ Cytotoxic T-lymphocytes are believed to mediate damage to hair follicles. ${ }^{5}$ Because our patient did not have an additional autoimmune disease before treatment initiation, it is tempting to speculate that a secondary autoimmune phenomenon trigged by treatment with alemtuzumab may have caused the hair loss described. Alemtuzumab-associated secondary autoimmunity has been reported in up to $48 \%$ of patients and encompasses B-cell-driven disorders. ${ }^{2,6}$ The high prevalence of this complication points to a potential predisposition in patients with MS. ${ }^{1}$ In our patient, we were able to detect slightly elevated antinuclear antibodies, which may be reflective of B-cell activation, but could also represent a nonspecific finding. It is important to note that to date, a dominant hairy cell-specific B-cell autoantigen has not been identified and a primarily B-cell-driven autoimmune response causing hair loss has not been established.

Depletion of CD52-positive cells by alemtuzumab is incomplete. ${ }^{2}$ It can therefore be anticipated that nondepleted cells could drive an early T-cell reconstitution through expansion, which would be in favor of immune populations that respond to self. This may explain, at least in part, the observed development of secondary autoimmunity after alemtuzumab. ${ }^{7}$ It is difficult to judge whether such an expansion would be significant enough to cause hair loss already 6 months after the last infusion of alemtuzumab. The skin biopsy may have been performed too late to detect lymphocytic infiltrates.

In conclusion, alopecia universalis in this patient with MS may have been triggered by the therapeutic application of the monoclonal antibody alemtuzumab. The time course and the exclusion of other differential diagnoses would support this view. Our observation re-emphasizes that pharmacovigilance is crucial when treating patients with innovative therapies.

\section{Author contributions}

V.I. Leussink treated the patient, analyzed and interpreted the data, and wrote the manuscript. H.-P. Hartung critically revised the manuscript and provided important intellectual content. J. Reifenberger treated the patient, acquired, analyzed, and interpreted additional data.

\section{Study funding}

No targeted funding reported.

\section{Disclosure}

V.I. Leussink received speaker honoraria from Biogen and Novartis. J. Reifenberger reports no disclosures. H.-P. Hartung served on the scientific advisory board of Novartis, Merck Serono, Teva, Biogen, Roche, Genzyme, BayerHealthcare, Sanofi, MedImmune, GeNeuro, Opexa, Octapharma, Receptos, Celgene, Roche, and Teva; received speaker honoraria from Biogen, Genzyme, Teva, Sanofi-Aventis, Merck, Novartis, Roche, and Bayer HealthCare; and is on the editorial board of Frontiers in Neurology/Frontiers in Immunology, European Journal of Neurology, Current Opinion in Neurology, and Nature 
Reviews Neurology. Full disclosure form information provided by the authors is available with the full text of this article at Neurology.org/NN.

Received October 16, 2017. Accepted in final form February 2, 2018.

\section{References}

1. Wiendl H, Kieseier B. Multiple sclerosis: reprogramming the immune repertoire with alemtuzumab in MS. Nat Rev Neurol 2013;9:125-126.

2. Menge $\mathrm{T}$, Stuve $\mathrm{O}$, Kieseier $\mathrm{BC}$, Hartung HP. Alemtuzumab: the advantages and challenges of a novel therapy in MS. Neurology 2014;83:87-97.
3. Spano F, Donovan JC. Alopecia areata: part 1: pathogenesis, diagnosis, and prognosis. Can Fam Physician 2015;61:751-755.

4. Rodriguez TA, Fernandes KE, Dresser KL, Duvic M; National Alopecia Areata Registry. Concordance rate of alopecia areata in identical twins supports both genetic and environmental factors. J Am Acad Dermatol 2010;62:525-527.

5. Xing L, Dai Z, Jabbari A, et al. Alopecia areata is driven by cytotoxic T lymphocytes and is reversed by JAK inhibition. Nat Med 2014;20:1043-1049.

6. Tuohy O, Costelloe L, Hill-Cawthorne G, et al. Alemtuzumab treatment of multiple sclerosis: long-term safety and efficacy. J Neurol Neurosurg Psychiatry 2015;86: 208-215.

7. Jones JL, Thompson SA, Loh P, et al. Human autoimmunity after lymphocyte depletion is caused by homeostatic T-cell proliferation. Proc Natl Acad Sci USA 2013; 110:20200-20205 


\title{
Neurology \\ Neuroimmunology \& Neuroinflammation
}

\author{
Case of alopecia universalis associated with alemtuzumab treatment in MS \\ Verena Isabell Leussink, Julia Reifenberger and Hans-Peter Hartung \\ Neurol Neuroimmunol Neuroinflamm 2018;5; \\ DOI 10.1212/NXI.0000000000000454
}

This information is current as of March 16, 2018

\section{Updated Information \& Services}

References

Subspecialty Collections

Permissions \& Licensing

Reprints including high resolution figures, can be found at:

http://nn.neurology.org/content/5/3/e454.full.html

This article cites 7 articles, 3 of which you can access for free at: http://nn.neurology.org/content/5/3/e454.full.html\#\#ref-list-1

This article, along with others on similar topics, appears in the following collection(s):

Multiple sclerosis

http://nn.neurology.org//cgi/collection/multiple_sclerosis

Information about reproducing this article in parts (figures,tables) or in its entirety can be found online at:

http://nn.neurology.org/misc/about.xhtml\#permissions

Information about ordering reprints can be found online: http://nn.neurology.org/misc/addir.xhtml\#reprintsus

Neurol Neuroimmunol Neuroinflamm is an official journal of the American Academy of Neurology.

Published since April 2014, it is an open-access, online-only, continuous publication journal. Copyright

Copyright (C) 2018 The Author(s). Published by Wolters Kluwer Health, Inc. on behalf of the American

Academy of Neurology. All rights reserved. Online ISSN: 2332-7812.

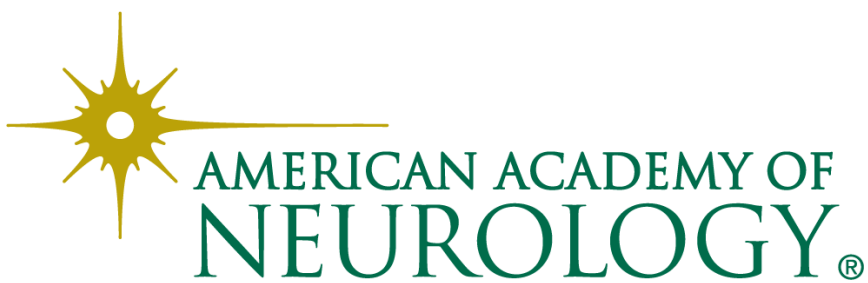

